Bari Diána Éva

Eötvös Loránd Tudományegyetem

bari.diana@gmail.com

\title{
VISSZAJELZÉSEK A NYELVÓRÁN \\ A NYELVMENEDZSMENT-ELMÉLET \\ MEGKÖZELÍTÉSÉN KERESZTÜL ${ }^{1}$
}

\section{Bevezetés}

A nyelvmenedzsment-elmélet az elöíró nyelvpolitikai megközelítéssel szemben a tényleges nyelvhasználót, annak sztenderdtől eltérő nyelvhasználatát helyezi vizsgálata középpontjába. Az elmélet metanyelvi tevékenységekre; a megnyilatkozások és beszédaktusok generálására, recepciójára, valamint azok menedzselésére, azaz nyelvpolitikai célok hatékony megvalósítására összpontosít. Ennek a célkitűzésnek a megvalósításához az elmélet a nyelvi eltéréseket és gátló tényezőket több szinten közelíti meg, amelyeket nem egymástól elkülönítve, hanem egymásra építkezve vizsgál (vö. Nekvapil 2006; Dovalil 2013, 2019).

A nyelvmenedzsment-elmélet rövid bemutatását követően a tanulmány az elmélet hibajavításra vonatkozó szemléletét tárgyalja, mivel a nyelv és a rá vonatkozó nyelvi korrekciók nemcsak a tanteremben, hanem a tantermen kívül is vitás helyzetek forrása lehet. Az elmélet széles körü alkalmazását bemutatva az elméleti részben a vállalati nyelvórai kontextust veszi alapul a dolgozat, ahol a nyelvtanár és a cég által közvetített nyelvhasználat bizonyos esetekben egymástól eltérő megoldásokat vázol. A dolgozat kitér a nyelvi normát meghatározó normaautoritásokra, viszont a normaszuverenitást sem hagyja figyelmen kívül annak normaalakító hatása miatt. A dolgozat második része egy empirikus kutatást mutat be: egy vizsgaközpont felülvizsgálati folyamatából néhány előzetesen kiválasztott példán keresztül szemlélteti a nyelvi szuverenitás és normaautoritás közti alkufolyamatokat, a nyelvmenedzsment-elmélet sokoldalú alkalmazásának igazolására.

\section{A nyelvmenedzsment-elmélet és annak folyamata}

Szintjeit tekintve megkülönböztetjük az egyszerű és szervezett menedzsmentet (JernuddNeustupný 1987; Dovalil-Šichová 2017). Az egyszerü menedzsment (online) olyan, azonnal bekövetkező javítási folyamat, amely legalább két nyelvhasználót feltételez.

1 A nyelvi és szakmai javaslatokat, pontosításokat és a támogatást ezúton is köszönöm Dormán Andrásnak (ELTE ONYC - ELTE-BTK). 
Ilyenkor az egyik fél vélt vagy valós többlettudással rendelkezik a másik félhez képest a hibaesemény bekövetkeztekor. Akkor beszélhetünk egy, a nyelvi produkcióból kiinduló nyelvmenedzsment-folyamatról, ha a hibaeseményt a beszélö(k)észlelik, mert megakasztja kettőjük interakcióját, vagy az ebben a helyzetben normaautoritásként elkönyvelt és hibajavítást végző fél a jelenséget zavarónak ítéli meg. Az észlelést (noting) egy értékelési folyamat (evaluation) során a javítói habitus és a cselekvési terv (adjustment design) alkalomhoz illő megválasztása követi. Ennek a folyamatnak minden eleme egyaránt lényeges, hiszen a javaslat megfogadása, azaz a cselekvési terv megvalósítása (implementation) egyben a javítás sikerességét is jelentheti. A folyamat utolsó lépéseként a javító a visszacsatoláson (feedback) át megbizonyosodhat afelől, hogy sikeres volt-e a hibajavítás. Ha az eltervezett intézkedéseket nem sikerült kellőképp kivitelezni, akkor a folyamat újra kezdődhet. Az egyszerủ menedzsment lefolyása gyors, nagyrészt spontán, így tudományos leképezése rendszerint retrospektív beszámoltatással valósítható meg a legjobban (vö. Jernudd-Neustupný 1987; Jernudd 1990; Nekvapil 2000; Dovalil 2013).

$\mathrm{Az}$ egyszerű menedzsmenttel ellentétben a szervezett menedzsment (offline) folyamata lassabb (Dovalil-Šichová 2017). Ha a beszélők egy olyan hibajelenségbe ütköznek, amely számukra megoldhatatlan feszültséget jelentene (pl.: de viszont vs. deviszont), akkor a nyelvi probléma felterjesztésre kerül szakemberek, intézmények, nyelvi kérdésekben jártas szaktekintélyek és normatekintélyek elé, hogy azok az adott nyelvi jelenséget illetően egy kivizsgálást követően megoldási javaslatot nyújtsanak (Ludányi 2019). Az ezen a színtéren lezajló nyelvmenedzsment mozzanatainak leírása könnyebb, mint a kivitelezésük, ugyanis a nyelvi norma kapcsán számtalan nehezítő körülmény bukkanhat fel. Erre vonatkozóan jelen dolgozat az elméleti háttér bemutatásakor az idegennyelv-órai helyzetre összpontosít, ahol joggal merülhet fel a kérdés: ki is az illetékes egy nyelvi probléma beazonosításakor a nyelvórán, és a helyes válasz elfogadása érdekében hogyan jár el a javító fél?

\section{A nyelvi probléma beazonosítása}

Nincs nyelvi sztenderd nyelvi probléma nélkül, és ez egyaránt értendő a célnyelvi, valamint a nyelvórai kontextusra vonatkozóan. Vít Dovalil ennek tükrében tárgyalja a nyelvi problémát, és felveti a kérdést, hogy egyáltalán nyelvi vagy társadalmi problémákról van-e szó a célnyelvi közösségben, ahol történetesen hatalmi problémák és társadalmi egyenlőtlenségek is teret kaphatnak (Dovalil 2013, 2019; vö. Dovalil-Šichová 2017). Német nyelvterületen ennek széles skálájával lehet találkozni, hiszen az utóbbi évtizedek társadalmi mozgásai egyben nyelvi kérdéseket is maguk után vontak, mint az angolt lingua francaként használó nemzetközi cégek. Bár más nyelvből is érkeztek jövevényszavak a német szókészletbe, az egyes átvételek korántsem bizonyultak annyira vitaindítónak, mint az anglicizmusok. Hasonlóan a magyar nyelvhez (pl.: lájkolni) a német is felvett angol kifejezéseket, a nyelvi rendszerébe iktatva használja, adott esetben a létező német kifejezések helyett. Német nyelvterületen puristák és a nyelvújítók vitatják 
az anglicizmusok létjogosultságát, hiszen a német beszélt nyelvváltozat lexikájára, valamint pragmatikájára rányomja a bélyegét, azaz: angolosodik a német írott sztenderd nyelvhasználat is (vö. Wagener 2012). Szintúgy német nyelvterületről érkezik a másik példa, nevezetesen a gendertudatos nyelvhasználat, ami kifejezetten az utóbbi években nyert teret és legitimációt. Mindez változásokat eredményezett vagy eredményez folyamatosan például a névelőhasználat kapcsán, az adminisztrációtól kezdve az eddig bevált formális és informális levelezési megszólításokon át. A rendkívül sok területet érintő jogi és törvényi szintű intézkedések inkább egy folyamat elejét jelzik, mintsem a végét (Braun et al. 2007; Kotthoff 2011; Thurner 2017; Diewald 2018).

A nyelvmenedzsment-elmélet kiemeli továbbá az eltérő érdekeltségeket, amihez szemléltető példa gyanánt a tanulmány a nemzetközi cégek nyelvpolitikai helyzetét említi meg. Egy Magyarországon tevékenykedő nemzetközi cég életében rendszerint a nyelvpolitikai kérdések mellékesek, általánosító jelleggel elmondható, hogy a helyzet szüli a nyelvhasználati szabályt. A cégen belüli nyelvi normát meghatározó autoritás a személyzeti osztályon tevékenykedő, nyelvi kérdésekben nem feltétlen kompetens személy (vö. Engelhardt 2009, 2011; Nekvapil et al. 2009). Minél több nyelven dolgozik egy adott cég, annál jellemzőb a babiloni helyzet, amelyben az egyes nyelvi kultúrák képviselői valamilyen úton-módon dolgozni és kommunikálni kényszerülnek egymással. A többségi nyelvet beszélő nyelvhasználó ilyenkor fölényben van, a megfelelő nyelv ismerete egyben (üzleti) haszonnal is jár, a nyelv hasznot hozó eszközzé válik. Továbbá a tényleges nyelvi kompetenciájuktól függetlenül szubjektív a munkatársak azon visszajelzése, hogy nem érzik a nyelvismeretüket elégségesnek, illetve az anyanyelvü nyelvhasználóhoz viszonyítva alárendeltségről panaszkodnak. Német tulajdonban levő vagy nemzetközi cégnél dolgozó, a német nyelvet nem anyanyelvi szinten beszélő személyek egyéni benyomása alapján ez a fajta nyelvi aszimmetria akkor egyenlítődik ki, ha mindkét fél angolra vált, közös nyelv gyanánt a magyar vagy a fogadó ország nyelve szóba se kerül (vö. Nekvapil et al. 2009). Így viszonylag sok cég - függetlenül attól, hogy német tulajdonban van az egyszerű menedzsment során az együttműködés optimalizálása érdekében megengedi az angol közvetítőnyelv használatát. Ha azonban például egy német cég megengedi, hogy a német és nem német munkatárs egymással angolul kommunikáljon a német helyett, és a munkatársak élnek is ezzel a lehetőséggel, akkor az számszerűleg csökkenti az adott cégen belül a német nyelv alkalmazását, függetlenül attól, hogy továbbra is németekkel zajlik a kommunikáció.

Végül, de nem utolsósorban az elmélet magyarországi vonatkozása sem elhanyagolható az anyanyelvi nevelésben, amelyben ez a szemlélet egy új megközelítést eredményezhet (Domonkosi-Ludányi 2020a, 2020b).

A bevezetés arra is kitért, hogy nyelvi probléma nemcsak a nyelvórai kontextusra korlátozódik, hanem vállalati, társadalmi szinten egyaránt bekövetkezhet. Ilyenkor a nyelvi problémát beazonosító illetékes indokoltan nem a nyelvész vagy a nyelvtanár, hanem egy hétköznapi szociokulturális kontextusban megnyilatkozó személy, az adott 
erődinamikai és hatalmi viszonyokkal. Azaz a hibajavítás színtere nemcsak az osztályterem vagy a nyelvóra lehet, ahol a javító személye a nyelvtanár, hanem lehet egy cég, ahol a javítási feladatok egy részét egy kolléga vagy felettes látja el. Társadalmi szintre lépve a nyelvet befolyásoló, értékelő és javító személyek kilétének meghatározása lehetetlen, hiszen méretéből és kiterjedéséből adódóan a döntéshozók többsége nem ismert. A nyelvi hiba beazonosítása, a korrektor személye és a hibaesemény színtere mellett egyaránt releváns a hibajavítás időpontja (Dovalil-Šichová 2017). Osztálytermi környezetben a rosszul időzített hibajavítás egyenesen kedvét szegheti a nyelvtanulónak. Vállalati szinten az üzleti és érvényesülési érdekek dominánsak: egy nagy erőfeszítéssel járó nyelvi tevékenységre adott, rosszul ütemezett elutasító válasz ugyancsak elcsüggesztheti a nyelvhasználót, például ha egy veszekedés után még a nyelvtudására is bíráló megjegyzést kap a munkatárs.

A dolgozat a továbbiak során a nyelvmenedzsment-elmélet által vázolt hibajavítási folyamatot szemlélteti.

\section{A hibajavítás folyamata a vállalati német nyelvóra példáján keresztül}

A dolgozat ezen fejezete egy olyan színtért idéz meg, ahol a nyelvi normát nemcsak a tanterem, hanem a vállalati környezet is befolyásolja: a német vállalati nyelvórai helyzetet. Szemléltetésként következzen az alábbi A1 szintnek megfelelő párbeszéd (1):

(1)

Diák: Ich mag den Auto.

Tanár: Das, tudod, o-ra végződik, mint Kino.

Diák: Das Auto, jó. De miért? Az angolban bezzeg ilyen nincs.

Ebben a helyzetben bármely németet tanító nyelvtanár mérlegeli, hogy mit is válaszoljon erre. A globalizált világban vitathatatlan az angol nyelv haszna (1. 3. fejezet). Ráadásul az angol nyelv szintaxisában nincs jelentősége a névelőknek. A német nyelvü országok legfontosabb gazdasági és kereskedelmi partnerei Magyarországnak. A közös történelmi múlt, a tudományfejlesztési területen jelen lévő együttműködések, az oktatási és tanulmányi ösztöndíjak magas száma mai napig erősítik a magyar-német kapcsolatokat (vö. Knipf-Komlósi 2018). Ezek az indokok egy kezdő szinten lévő diáknak nem bizonyulnak elégségesnek ahhoz, hogy hosszabb távon is elmélyítse német nyelvi ismereteit. E fent vázolt helyzetben a nyelvmenedzsment-elmélet szerint a tanár helyett a diákot és az ôt gátló folyamatokat kell vizsgálat tárgyává tenni, azok közül is azokat, amelyek a diákot a korrekciós javaslat megfogadásában akadályozhatják. A nyelvmenedzsment-elmélet hibajavításra vonatkozó meglátásait és javaslatait a jelen tanulmány következő alfejezetei tárgyalják. 


\subsection{Szociokulturális/szocioökonomiai/ideológiai menedzsment}

Az elmélet terminológiájával élve a fenti esetben egy olyan nyelvi probléma került elö, ahol a tanári észrevételére és a grammatikai szintủ hibajavításra a diák visszacsatolásként nem helyeslően elfogadta azt, továbbá a példában említett grammatikai szabályt nem tette magáévá, hanem ideológiai szempontból válaszolt „bezzeg az angol”). A tanár ebben a szocioökonómiai kontextusban normaautoritás, azaz rendelkezhet - szerepköréből adódóan - megengedően vagy regulázóan habitusának és hitvallásának megfelelően, ami egyénenként változó lehet.

Szemléltetés gyanánt az alábbi lehetséges tanári válaszadásokat vezeti fel a dolgozat.

\subsubsection{A megengedö válasz}

A megengedő válasz értelmében a tanár vigasztaló szándékkal utalhat arra, hogy „ezt a németek is elrontják, ne aggódj", aminek köszönhetően az óra nem akad meg hosszú időre. Nem kizárt azonban, hogy innentől fogva a diák a következő hibajelenségnél ezt feljogosításknak fogja értelmezni, és kevésbé fog a helyes nyelvhasználatra ügyelni.

\subsubsection{A grammatikai válasz megismétlése}

A rendszerezett nyelvtani ismeretek átadása mellett a hibajavítás elfogadására vonatkozó másik megközelítés a szabályszerűségek megismétlése, ami általában beletörődéshez vezet. Nem akasztja meg az óra menetét, viszont a félévi tematika mikromenedzselését eredményezheti, mivel a gyakorlatorientált megközelítés rovására mehet.

\subsubsection{A kulturális válasz}

A Közös Európai Referenciakeret (W1) értelmében a nyelvóra egyben kulturális ismeretek átadására is alkalmazható, hogy „elősegítse a tanulók teljes személyiségének és identitástudatának megfelelő fejlődését a nyelvi és kulturális másság ismeretében”, azaz a nyelvtörténeti szempontú magyarázatadás érdeklődést és empátiát gerjeszthet a diákban. Ez a következő lépéshez, az ún. kommunikatív menedzsmenthez vezethet (1. 4.2), feltéve ha a tanár rendelkezik megfelelő nyelvtörténeti háttérismerettel - és egyben hajlandósággal, hiszen ez az órai felkészülést is meghosszabbíthatja, továbbá időbeli többletráfordítást jelenthet, amit az egyes iskolák tanterve nem tesz lehetővé, valamint a diák háttértudása és érdeklődése is szükséges hozzá.

\subsubsection{Az anglicizmusok, azaz bezzeg az angol}

Egyéni megfigyelések alapján az anglicizmusok nyelvórai használata képes purista nézeteket kiváltani a diákokból, aminek következtében gondosabban ügyelnek a diákok a helyes nyelvhasználatra. Ez természetesen csak egy megfigyelés, amely több utánajárást kíván, viszont a tiltás helyetti megengedőbb szemlélet sokkal inkább belátáshoz vezet, így nem egy elhanyagolható aspektus, amit a jövőben érdemes tovább vizsgálni. 


\subsubsection{Nincs visszajelzés}

Van, amikor a tanár a diák visszajelzését figyelmen kívül hagyva továbblép, nem támogatja a további párbeszédet. Ennek számos oka lehet, erre azonban a tanulmány terjedelmi korlátokból kifolyólag nem kíván hosszabban kitérni. Az így keletkező helyzet összetettsége bár tagadhatatlan, ugyanakkor ún. szocioökonómiai és szociokulturális menedzsment nélkül a tervezett hibajavítás befogadása is nehezebbnek, sőt akár lehetetlennek bizonyulhat.

\subsection{Kommunikatív menedzsment}

Ez a menedzsmentszint a tanár és a diák közti interakciós színteret érinti; a stilisztikai és pragmatikai aspektusok mellett a fonetikai tényezők egyaránt ide sorolandók. Sikerességét illetően viszont szorosan összefügg az előbb említett szociokulturális és ideológiai menedzsmenttel (1.4.1). A nyelvi hibák rendezése ugyanis időt, energiát vesz igénybe, azaz a diák és a tanár részéről egyaránt erőfeszítést igényel. Amennyiben a diák a menedzsmentfolyamatokat „drágállja”, azaz túl sok erőfeszítést igénylőnek tartja, hasznát az adott szinten még nem érzi kézzel foghatónak, akkor a nyelvmenedzsment-elméletben használt fogalmakkal élve egy gyorsabb nyereséggel és magasabb hozammal járó befektetés mellett dönthet. Példánknál maradva: a bezzeg az angol ideológiai megközelítés esetében felmerülhet az a kérdés, hogy mennyire érdemes egyáltalán a helyes és nyelvtani értelemben is megfelelő névelőhasználattal foglalkoznia a tanárnak kezdőszinten, elvégre a mondat jelentéstartalmán keveset módosít, még hibás használatkor is kikövetkeztethető marad a mondat értelme a célnyelvi nyelvhasználó számára, ami átfedésben van a KER A1 nyelvi szint követelményrendszerével. Így bár a köznyelvi norma szempontjából nézve a hibajavítás szükséges, ha a gazdaságosság szempontját is figyelembe vesszük: das Auto egy olyan alapszó, amely a nyelvtanulói alapszókincs része, és valószínű, hogy a későbbiek során, több nyelvi jártasságot szerezve a diák saját magát fogja javítani. Nem a helyes nyelvhasználatra való törekvés miatt, hanem pusztán azért, mert az adott szó a szókészlet gyakori eleme. Ilyen esetben a normaautoritás megengedően viselkedik, s innentől kezdve a diák is alakítani fogja a nyelvórán érvényben lévő, ott létrejövő nyelvi normát, ugyanis a nyelvóra kontextusában nyelvi szuverenitássá válhat (vö. Hundt 2009: 117).

\subsection{Nyelvi menedzsment}

Tételezzük fel, hogy a diák nyitottabbá és befogadóbbá vált a javítási javaslattal szemben, lexikai, nyelvi és grammatikai értelemben bekövetkezhet a javítás, és elviekben a nyelvi igényessége lépésről lépésre nőhet, amennyiben az őt gátló ideológiai ingerektől megszabadult. A nyelvmenedzsment-elmélet hibajavításra vonatkozó szintrendszere ezzel a lépcsőfokkal zárul. 


\section{A nyelvi sztenderd erődinamikája}

Hogy egy németórán nyelvi sztenderdről beszélni lehessen, érinteni kell a német nyelvi sztenderd körüli vitát, amiben a nyelvet alakító szereplők kiléte régóta vita tárgya. A norma kérdéskörét sokan kutatták és kutatják, jelen tanulmány pedig Ulrich Ammon (1995) tevékenységére hivatkozik, aki a nyelvi sztenderdet meghatározó szereplők beazonosítását az alábbi ábra segítségével szemlélteti.

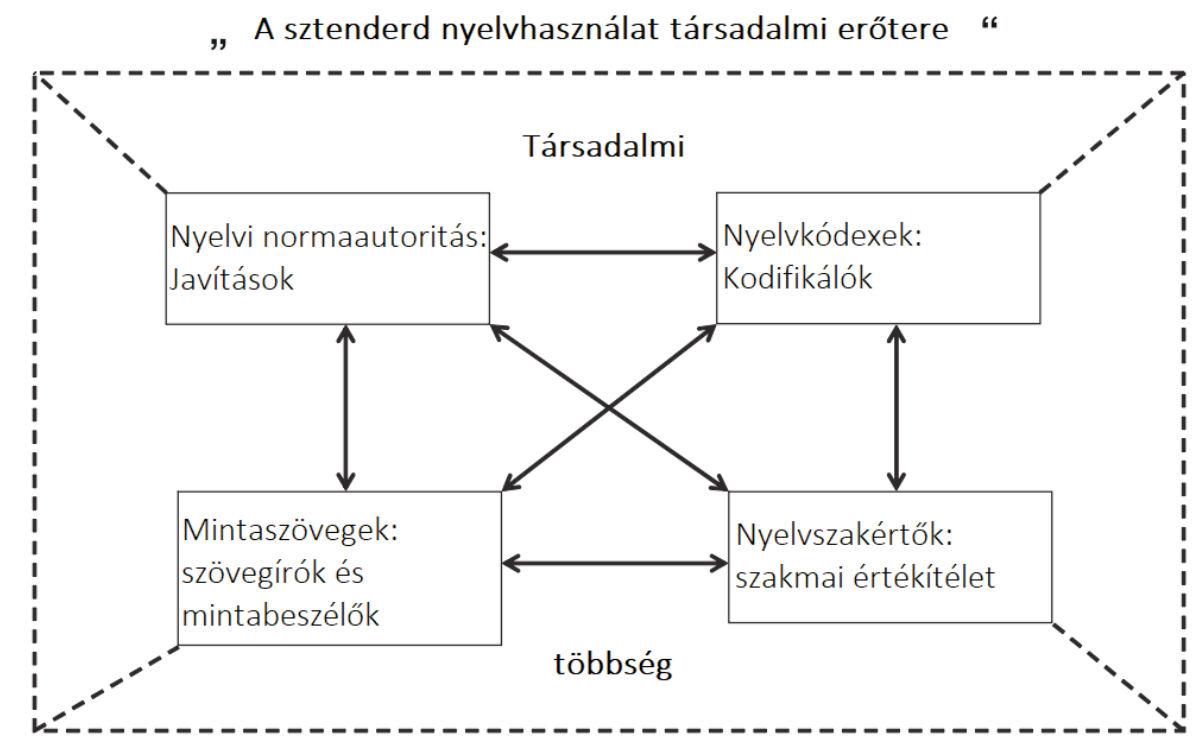

1. ábra: Ulrich Ammon (1995: 80): A sztenderd nyelvhasználat társadalmi erőtere

Ammon (1995: 73-82) „A sztenderd nyelvhasználat társadalmi erőtere” (Soziales Kräftefeld einer Standardvarietät) (1. ábra) modellje alapján a lakosságba (Bevölkerungsmehrheit) ágyazza a nyelvi sztenderdet őrző szereplőket (vö. Hundt 2009, az egyszerű nyelvhasználót szintúgy normaalakítónak ítéli, l. lent).

1. Normautoritäten, azaz a normaautoritások jogosultak javításokat végezni.

2. Sprachkodex (Kodifizierer), azaz a szótárak és lexikonok, tankönyvek (és létrehozóik).

3. Modellsprecher/-schreiber és Modelltexte: mintaszövegek alkotói és a mintabeszélők, pl. az írott és beszélt sajtó képviselői

4. Sprachexperten: szakemberek, akik szakmailag értékítéletet hozhatnak.

Ahogyan az ábrából kitủnik, ez a négy résztvevő egymással kölcsönhatásban és folyamatos interakcióban áll.

Hundt (2009) szerint Ammon modelljének kiegészítésére van szükség, mivel a nyelvi szuverenitást képviselő hétköznapi beszélő nem elhanyagolható. Felhívja a figyelmet 
a hétköznapi beszélőnek a nyelvi sztenderdet befolyásoló szerepére, elvégre a szervezett menedzsment szintjén tárgyalt nyelvi problémák többnyire időben erősen megkésve válnak a kutatás tárgyává: akkor, amikor a nyelvi hiba vagy normától eltérő nyelvhasználat már rég a köztudatba került, és széles körű használatnak örvend. Ebből adódóan a megjelent szótárak, lexikonok és a KER szerint összeállított tankönyvek bár referenciapontok, a német nyelv gyors fejlődése miatt, illetve az egyes nyelvi területek (pl.: magyar-német viszonylatban a belső vállalati kommunikáció) ismeretlensége és hozzáférhetetlensége miatt felmerülhet, hogy adott esetben nem tudnak megfelelő támpontot nyújtani (Bari 2018).

Ebből adódóan joggal vetődhet fel német nyelvi órán a kérdés: mi alapján javít a nyelvtanár, hogy az a nyelvi sztenderdnek, a gyakran idézett Hochdeutschnak megfelelhessen - mindezt úgy, hogy egy olyan nyelvről van szó, amely dinamikáját tekintve a számtalan demográfiai és gazdasági változónak köszönhetően a szemünk láttára alakul és változik (vö. Knipf-Komlósi 2012). Bár a dolgozat most a tanárt mint normaautoritást nem tárgyalja, megjegyzi, hogy a visszajelzést a nyelvtanár adja, aki szintúgy rendelkezik egy háttérismerettel, saját szociokulturális háttérrel és számos viselkedéstani együtthatóval, amely őt a hibajavitás időpontjában és a norma iránti érzékenységében egyaránt befolyásolja.

A németórai normát érintő kérdések tovább színesedhetnek, ugyanis Magyarországon nemcsak iskolai környezetben, hanem a magánszektorban is zajlik nyelvoktatás, ahol a norma körüli kérdéseket hatalmi tényezők is alakítják, azaz a cégszintű nyelvhasználat merőben eltérhet a sztenderd által megkövetelt elvárásoktól. Így tovább tágul a javítási tervezet a német nyelvi normát illetően, és kérdésfelvetésként felmerülhet, hogy miként alakítja a javítói habitusát a nyelvtanár, aki:

- nem rendelkezik azzal a szükséges tapasztalattal, amit a munkaerőpiac adott szegmense megkíván, elvégre tanárként nem dolgozott cégnél;

- a megfelelő nyelvi normák nem vagy csak egy későbbi nyelvi szinten érintettek;

- a választott/forgalomban levő tankönyvek nem fedik le a megfelelő szaknyelvi árnyalatokat és pragmatikai különbségeket, illetve nem szolgálnak elegendő támponttal;

- a nyelvtanuló tapasztalatai eltérnek a tanár tapasztalataitól;

- saját célnyelvi tapasztalatokkal kevésbé rendelkezik;

- fiatalabb, mint a nyelvtanuló, vagy túl nagy a korkülönbség;

- a nyelvtanuló a cégnél magasabb pozíciót tölt be, adott esetben a cég szempontjából nézve normatekintély.

Dovalilnak (2011) a cseh nyelvtanárok körében végzett felmérése alapján kiderül, hogy a nyelvtanárok kétes helyzetekben nyelvautoritásként nem minden esetben nyúlnak lexikonokhoz, hanem a nyelvkönyvek mellett anyanyelvi nyelvhasználókhoz fordulhatnak tanácsért, akiket képzettségtől függetlenül a nyelvi probléma megvitatásakor 
szakértőként címkéznek fel. Hasonló észrevételek megfigyelhetők a vállalati nyelvoktatásnál is, ahol megfelelő szakirodalom és előképzettség híján a nyelvóra résztvevői, azaz a tanár vagy a nyelvtanuló vagy a kollégájához, vagy pedig anyanyelvi beszélőhöz fordul tanácsért. Az anyanyelvi beszélő ugyanakkor nem mindig jelenti azt, hogy megfelelő anyanyelvi kompetenciával rendelkezik az illető, ugyanis bár lehet tőle megerősítést kérni, viszont ez nem feltétlen jelenti, hogy megfelelő indoklást is tudnak hozzá társítani.

\section{Visszajelzések szerepe a nyelvvizsgáknál}

Mivel a tanulmány egyik célja a nyelvmenedzsment-elmélet sokoldalú felhasználásának bemutatása, kitérek a nyelvvizsgák kérdésére is. A javító és vizsgázó értékeléskor nem találkozik, ez a nyelvi mérés egyik objektív követelménye is. A Magyarországon évtizedek óta müködő vizsgaközpontok nem értékelhetnek tetszőlegesen; a vizsgáztató kiképzését a hatályban levő jogszabályok megfelelő végzettséghez és tapasztalathoz kötik. Kiemelten eleget kell tenni a nyelvi kritériumnak, mivel a javítók a KER-skálák által meghatározott nyelvi sztenderd megfelelő méréséért felelnek, ellenőrizhetők és felelősségre vonhatók.

A vizsgaeseményt és az értékelési időszakot követően a vizsgázót megilleti az a jog, hogy a javítói tevékenységet véleményezze, így a betekintési és felülvizsgálati időszakban érvekkel vagy érvek nélkül kérvényezheti az értékelése felülvizsgálatát, függetlenül attól, hogy látta-e a dolgozatát vagy sem. A felülvizsgálatot végző személy ebben az esetben egy harmadik javító és vizsgáztató, aki rendelkezik azzal a felkészültséggel, hogy szükség esetén felülbírálhassa a javítói tevékenységet. A kérelem elbírálásakor a vizsgarendszer KER-hez igazított skálarendszere, mintamegoldások, valamint kétes esetekben a normatív nyelvtanok, lexikonok és szótárak segítségével a dolgozat értékelését felülvizsgálja, kérvény esetén újraértékeli, majd a döntésről írásban, indoklással egyetemben értesíti a vizsgaközponton keresztül a vizsgázót. Az emberi tényezőből származó szubjektivitás a javítóknál még a kettős értékelés rendszere mellett sem zárható ki teljesen, így a felülvizsgálati jogot a vizsgarendszerek meghagyják a vizsgázónak. A megfelelő visszajelzés a vizsgarendszer hírét és presztízsét emeli.

A kérvényt írók leggyakrabban középiskolások, esetleg fiatal felnőttek, akik korukból és egyéb szociokulturális, valamint viselkedéstani tényezőkből adódóan a mindenkori nyelvi sztenderdtől eltérően fejezik ki magukat. A felülvizsgálatok egy igen szembetűnő részét pont a szinonimák használatára való hivatkozások képzik, függetlenül attól, hogy a javítók értékeléskor az egymással teljes mértékben ekvivalens kifejezéseket elfogadhatják. A következőkben erre szerepeljen egy példa egy középfokú nyelvvizsgából:

\begin{tabular}{|c|c|}
\hline Mintamegoldás & Válasz \\
\hline gazdaságilag függetlenné tette & függetlenül gazdálkodhatott \\
\hline
\end{tabular}


A nyelvi sztenderdet szem előtt tartva az értékelők a gazdálkodhatott használatát nem minősítették megfelelőnek. A kérvény elbírálásakor a Magyar Szinonimaszótár nyújtott megoldást: a szóban forgó kifejezést a nyelvi sztenderdtől bár eltérően, mégis kontextusnak megfelelően adta meg a kérelmező, úgyhogy a felülvizsgálatot végző értékelő helyt adott a kérelemnek. Mivel a vizsga nem diszkriminálhat, így ez az egy esemény a többi dolgozat áttekintését és a hivatalos megoldókulcs bővítését vonta maga után.

Nézzünk meg egy másik példát, ahol egy másik kérelmező ugyanúgy a szinonim szóhasználatra hivatkozva nyújtotta be kérelmét:

\begin{tabular}{|c|c|}
\hline Mintamegoldás & Válasz \\
\hline így a kérést továbbította & a kérését továbbszállította \\
\hline
\end{tabular}

Mivel indoklás nélkül nem lehet elutasítani egy kérelmet, itt is a Magyar Szinonimaszótár iránymutatásához fordult a felülvizsgálat, ahol a továbbit szinonimájaként valóbanfel volt tüntetve a tovább szállít volt felvezetve. Ekvivalens megfeleltetés esetében fogadható el a használt szinonima, tehát a szövegkörnyezetbe is megfelelően bele kell illenie, ebben az esetben ez a kritérium nem teljesült.

Mindkét példa esetében volt egy-egy előre rögzített megoldókulcs, ahol viszonylag jól nyomon lehetett követni a változókat. Ugyanakkor az is érzékelhető, hogy az elöre rögzített, a javítóbizottság által jóváhagyott, standardizált megoldások a normaszuverenitás hatására adott esetben mennyire könnyen hígulhatnak, ugyanis egy nem megfelelő visszajelzés akár jogi következményeket is vonhat maga után.

\section{7. Összegzés}

Jelen tanulmány a nyelvmenedzsment-elmélet hibajavítási szintjein keresztül amellett érvelt, hogy a klasszikus hibajavítással ellentétben a nyelvi sztenderdtől való eltérések szélesebb körben interpretálhatók. A nyelvmenedzsment-elmélet alkalmazhatósági köre sokrétű, előbbre rangsorolja a nyelvhasználó viselkedéstani, kulturális, gazdasági, valamint ideológiai viszonyulását a nyelvhez, hogy mindezek ne szerepeljenek befogadáskor akadályozó tényezőként. A szocioökonómiai menedzsmentet követő kommunikativ menedzsment feltételezi a megfelelő és helyes példákat, hogy a nyelvhasználó a gazdaságból ismert költség-haszon elve alapján ne felesleges fáradságként, hanem befektetésként kezelje a nyelvtudása gyarapítását, hogy ez alapján ne keressen mentséget a hanyag nyelvhasználatát illetően. Bár tagadhatatlan azon nyelvhasználók jelenléte, akik a saját anyanyelvüket és az általuk választott idegen nyelvet motiváltan elsajátították el és ápolják, jelen tanulmány az olyan nyelvhasználókkal kapcsolatban értekezett, akik egy bizonyos kényszer (pl.: a nyelvtudás dokumentummal történő igazolása) vagy érdek (pl.: munkaerőpiaci boldogulás) hatására tanulnak nyelvet. A tanulmány érintette a nyelvi sztenderd sokrétűségét és áttekintette a normát alakító szereplőket (vö. Ammon 1995 - 2019-ben 
bekövetkezett haláláig). Hundt (2009) és Dovalil (2011) nyomán elemezte a nyelvmenedzsment-elmélet alapján a normaszuverenitást képviselő átlag nyelvhasználót, aki végez nyelvi normát alakító tevékenységet, ami a német esetében a nagyfokú variabilitása és gyors nyelvi változása miatt nehezen leképezhető. A visszajelzésekhez gyakorlati példákat hozott a középfokú nyelvvizsgák felülvizsgálataiból, ahol a szinonimákon keresztül azt szándékozta szemléltetni, hogy egy egyszerủ szinonima elfogadásával, illetve elutasításával mennyire könnyen hígulhat vagy szigorodhat a nyelvi norma; hogy a korrektor, a lexikonok, de a nyelvi szuverenitást képviselő személyek is hatást gyakorolnak egymásra, és állandóan hol egymással, hol egymás ellen érvelnek. Akarva, akaratlanul is.

\section{Irodalom}

Ammon, Ulrich 1995. Die deutsche Sprache in Deutschland, Österreich und der Schweiz. Das Problem der nationalen Varietäten. Berlin, New York: de Gruyter. https://doi.org/10.1515/9783110872170

Bari, Diána Éva 2018. Der Gemeinsame Europäische Referenzrahmen aus dem Blickwinkel der Sprachmanagementtheorie. In: Nyakas Judit (szerk.): Lingua Tanulmánykötet. Corvinus Nyelvi Napok. Szaknyelvoktatás és vizsgáztatás perspektivái - interkulturális kihivások a nyelvoktatásban. Budapest: Budapest Corvinus Egyetem. 131-141.

Braun, Friederike - Oekelrs, Susanne - Rogalski, Karin - Bosak, Janine - Sczesny, Sabine 2007. „Aus Gründen der Verständlichkeit...”: Der Einfluss generisch maskuliner und alternativer Personenbezeichnungen auf die kognitive Verarbeitung von Texten. Psychologische Rundschau 58/3: 183-189. https://doi.org/10.1026/0033-3042.58.3.183

Diewald, Gabriele 2018. Zur Diskussion: Geschlechtergerechte Sprache als Thema der germanistischen Linguistik - exemplarisch exerziert am Streit um das sogenannte generische Maskulinum. Zeitschrift für germanistische Linguistik. Deutsche Sprache in Gegenwart und Geschichte 46/2: 283-299. https://doi.org/10.1515/zgl-2018-0016

Domonkosi Ágnes - Ludányi Zsófia 2020a. A nyelvmenedzsment-elmélet lehetöségei az anyanyelvi nevelésben. In: Hoss Alexandra - Viszket Anita (szerk.): Találkozások az anyanyelvi nevelésben 4. Hasonlóságok és különbözöségek a nyelvben és az anyanyelvi nevelésben. Pécs: PTE BTK Nyelvtudományi Tanszék - Lingua Franca Csoport. 41-50.

Domonkosi Ágnes - Ludányi Zsófia 2020b. Problémaalapú szemlélet az anyanyelvi nevelésben. In: Istók Béla - Lőrincz Gábor - Lőrincz Julianna - Simon Szabolcs (szerk.): Tankönyvkutatás - forditott tankönyvek - kétnyelvüség. A Variológiai Kutatócsoport nemzetközi tankönyvkutató szimpóziumának elöadásai. Komárom: Selye János Egyetem Tanárképző Kara. 177-192.

Dovalil, Vít 2011. Sprachnormen im Schulunterricht: Eine Untersuchung aus soziolinguistischer Perspektive. In: Lejsová, Alena - Valdrová, Jana (Hrsg.): Die Grammatik, Semantik und Pragmatik des Wortes. Ihre Erforschung und Vermittlung. Ausburg: Wißner Verlag. 65-88. 
Dovalil, Vít 2013. Soziales Kräftefeld einer Standardvarietät als methodologischer Impuls für die Debatte über die Standardnormen. In: Schneider-Wiejowski, Karina - Kellermeier-Rehbein, Birte - Haselhuber, Jakob (Hrsg.): Vielfalt, Variation und Stellung der deutschen Sprache. Berlin, Boston: De Gruyter. 65-78.

Dovalil, Vít 2019. Förderung von Deutsch als Fremdsprache in Tschechien: Theoretische Voraussetzungen und praktische Konsequenzen. In: Ammon, Ulrich - Schmidt, Gabriele (Hrsg.): Förderung der deutschen Sprache weltweit: Vorschläge, Ansätze und Konzepte. Berlin, Boston: De Gruyter. 701-718. https://doi. org/10.1515/9783110479232-043

Dovalil, Vít - Šichová, Kateřina 2017. Sprach(en)politik, Sprachplanung und Sprachmanagement. Literaturhinweise zur Linguistik. 6. kötet. Universitätsverlag Winter Heidelberg. https://doi.org/10.33675/2017-82537715

Engelhardt, Oliver 2009. Die Sprachpolitik eines deutschen Industriebetriebs in der Tschechischen Republik und ihre Verwirklichung. Bohemica Olomucensia 3: 173-182.

Engelhardt, Oliver 2011. Management of multilingualism in multinational companies of German origin in the Czech Republic. In: Garzone, Giuliana - Gotti, Maurizio (eds.): Discourse, Communication and the Enterprise: Genres and Trends. Bern: Peter Lang. 11-129.

Hundt, Markus 2009. Normverletzungen und neue Normen. In: Konopka, Marek Strecker, Bruno: Deutsche Grammatik - Regeln, Normen, Sprachgebrauch. Berlin, New York: De Gruyter. 117-140.

Jernudd, Björn H. - Neustupný, Jiři V. 1987. Language Planning: For Whom? In: Laforge, Lorne (ed.): Proceedings of the International Colloquium on Language Planning. Québec: Les Presses de L'Université Laval. 69-84.

Jernudd, Björn H. 1990. Two approaches to language planning. In: Bickley, Verner: Language Use, Language Teaching and the Curriculum. Hong Kong: Institute of Language in Education, Education Department. 48-53.

Knipf-Komlósi, Erzsébet 2012. Nationale Varietäten und sprachliche Variation am Beispiel des Deutschen - Eine Problemskizze. In: Szabó Dávid (szerk.): Szavak, frazémák, szótárak. Irrások Bárdosi Vilmos 60. születésnapjára. Budapest: ELTE BTK Francia Tanszék - Egyetemközi Francia Központ. 33-45.

Knipf-Komlósi, Erzsébet 2018. Das Dilemma zwischen Norm und Variation im Deutschunterricht in Ungarn - und wie Lehrende darüber denken. In: Lenz, Alexandra Nicole - Plewnia, Albrecht (Hrgs.): Variation - Normen - Identität. Germanistische Sprachwissenschaft um 2020. Vol. 4. Berlin, Boston: De Gruyter. 197-218. https://doi.org/10.1515/9783110538625-009

Kotthoff, Helga 2011. Anglizismen sind das neue Imponier-Deutsch. Zeit, 2011. november 9. https://www.zeit.de/wissen/2011-11/anglizismen-wissenschaftssprache (2020. 02. 19.) 
Ludányi, Zsófia 2019. Language ideologies in Hungarian language counselling interactions. Eruditio - Educatio 14/3: 59-76.

Nekvapil, Jiři 2000. Language management in a changing society: sociolinguistic remarks from the Czech Republic. In: Panzer, Baldur (ed.): Die sprachliche Situation in der Slavia zehn Jahre nach der Wende. Frankfurt am Main: Peter Lang. 165-177.

Nekvapil, Jiři 2006. From language planning to language management. Sociolinguistica 20: 92-104. https://doi.org/10.1515/9783484604841.92

Nekvapil, Jiři-Sherman, Tamah - Balogh, Erzséber - Tápainé Balla, Ágnes Engelhardt, Oliver 2009. Interakció előtti menedzselés multinacionális nagyvállalatoknál Közép-Európában. In: Lanstyák István - Menyhárt József - Szabómihály Gizella (szerk.): Tanulmányok a kétnyelvüségröl IV. Dunaszerdahely: Gramma Nyelvi Iroda. 24-46.

Nekvapil, Jiři - Sherman, Tamah 2013. Language ideologies and linguistic practices: The case of multinational companies in Central Europe. In: Barát, Erzsébet - Studer, Patrick - Nekvapil Jiři (eds): Ideological Conceptualizations of Language: Discourses of Linguistic Diversity. Frankfurt am Main: Peter Lang. 85-117.

Neustupný, Jiři V. 1994. Problems of English Contact Discourse and Language Planning. In: Kandiah, Thiru - Kwan-Terry, John (eds.): English and Language Planning: A Southeast Asian Contribution. Singapore: Academic Press. 50-69.

Thurner, Ingrid 2017. Der Gender-Kampf verhunzt die deutsche Sprache. https://vds-ev.de/ wp-content/uploads/2017/02/deutschinsgg_aufsatz_thurner.pdf (2020. 02. 19.)

Wagener, Hans 2012. Untergräbt Deutschland selbst die internationale Stellung der deutschen Sprache? Eine Folge der Förderung von Englisch im Bildungsbereich. Duisburger Arbeiten zur Sprach- und Kulturwissenschaft. Vol. 93. Frankfurt am Main: Peter Lang. https://doi.org/10.3726/978-3-653-01943-8

\section{Internetes hivatkozások}

W1 = Közös Európai Referenciakeret 2002. https://nyak.oh.gov.hu/nyat/doc/ker_2002. asp (2019. 04. 30) 